Original Research

\title{
Investigating Biomass Formations at Different Depths in a Slow Sand Filter
}

\author{
Neslihan Manav Demir, Elif Burcu Atci, Selami Demir, Aykut Karadeniz \\ Yildiz Technical University, Faculty of Civil Engineering, Environmental Engineering Department, \\ 34220 Esenler, Istanbul, Turkey
}

Received: 7 July 2017

Accepted: 3 September 2017

\begin{abstract}
A laboratory-scale slow sand filtration (SSF) system was used to investigate biomass formation in different depths of SSF depending on various operating conditions in regard to filtration rate and influent iron-manganese concentrations. Results suggest that biomass formation occurs mainly in the uppermost $1.5 \mathrm{~cm}$ of the filter bed with slight contributions from layers between $1.5 \mathrm{~cm}$ and $14.5 \mathrm{~cm}$. The highest volatile solids (VS) accumulation was observed in the uppermost layer as $16.93 \pm 0.07 \mathrm{mgVS} / \mathrm{g}$ dry sand, and the accumulation was found to be a function of both filtration rate and influent iron-manganese concentrations. Hydraulic conductivities were tested as a measure of biomass formation. The highest initial value of hydraulic conductivity was measured as $13.7 \mu \mathrm{m} / \mathrm{s}$, while the lowest values ranged from 3.28 to $6.62 \mu \mathrm{m} / \mathrm{s}$ at the end of 55 days of operation. Hydraulic conductivities of the upper layers decreased quickly with time, while slight reductions were observed in hydraulic conductivities of the lower layers.
\end{abstract}

Keywords: slow sand filter, iron-manganese removal, biomass formation, headloss, hydraulic conductivity

\section{Introduction}

As a result of continuous increases in the world's population, the need for drinking water is also increasing. Today, the use of water resources is about 6 times that of the 19th century. Clean water is the fundamental component of daily life; unfortunately, fresh water sources are becoming scarcer and a clean water supply has become a luxury - especially for rural areas.

Usually surface and groundwater sources are used for potable water supplies. Since iron and manganese are major components in soil, surface and ground water

*e-mail:nmanav@yildiz.edu.tr sources contain high concentrations of these metals [1]. Although several techniques have been employed for removing these metals, increasing water demand calls for new techniques that meet this requirement via cheaper and more reliable processes, or upgrading current treatment techniques to provide an easier and cheaper solution to this problem. Slow sand filtration that employs physical, chemical, and biological processes [2] is one of those techniques that can meet water demand in towns and small cities [3]. Slow sand filters (SSFs) have been used for more than 200 years to treat potable water. Because of their simple operation [4], low cost [5], and high efficiency, engineers return to use SSFs for potable water treatment [6]. For instance, there are 170 SSFs for water treatment in the USA and 12 in Zurich, Switzerland [7]. 
The main difference between rapid and slow sand filters is that the treatment takes place in a biologically active medium in SSFs [8]. It is possible to achieve high treatment efficiencies in SSFs with slow rates of filtration through the sand medium that contains fine sand particles (effective size is 0.1 to $0.3 \mathrm{~mm}$ ). Besides, the biological actions within the biofilm layer accumulated in a few centimeters at the top of the filter bed also contribute to treatment $[4,9]$. This gelatinous and greasy [10] biologically active layer within the medium that is formed as a result of the presence of substrates and nutrients in the feed water is called schmutzdecke [11], where available organic material in the feed water is metabolized by the consortium of present biological agents [12]. Formed within 3 to 7 days after startup, schmutzdecke develops and contributes to treatment efficiencies in SSFs [13], and its presence can be associated with the high headloss through the filter bed [14-15]. Schmutzdecke usually contains bacteria, algae, protozoa, and some extracellular products [15-16], and is responsible for reducing high concentrations of organics as well as pathogens $[12,17-$ $18]$.

Collecting representative samples of schmutzdecke and the sand medium during the operation is somewhat difficult, thus different approaches have been used to determine the microbial biomass concentration in the schmutzdecke layer [19]. In his own work, Livingston [20] used EDX (energy dispersive x-ray spectroscopy) analysis and zeta-potential measurements to investigate the schmutzdecke layer. Joubert and Pillay [21] and Li et al. [22] observed the development of microbial biomass using environmental scanning electron microscopy (ESEM) and laser scanning microscopy, respectively. Until today, several researchers, such as Campos et al. [2324], have developed models to describe the development of schmutzdecke. Campos et al. [14] identified the total microbial biomass concentration as "sand biomass" and measured it using the modified chloroform fumigationextraction technique.

Another commonly used parameter for describing the schmutzdecke development is the hydraulic conductivity (K-value) [25]. Since the K-value of a saturated soil stands for the average conductivity of that soil, and it depends on the size and shape of particles as well as spatial distribution of pores [26], the K-value could be used as a measure of the biofilm accumulation within the sand medium. The decrease in the K-value of SSF medium is, therefore, a sign of loss of a medium's permeability [27], and schmutzdecke development, which can be measured experimentally [28]. Unfortunately, research on hydraulic characteristics of the media in SSFs is limited [25] and new research is required to fill the gap.

In this study, biofilm accumulation in a laboratoryscale slow sand filter was investigated. In experiments, iron, manganese, turbidity, and total organic carbon (TOC) removal efficiencies were also monitored. Besides, samples were collected at various depths of the SSF during the operation and analyzed for turbidity, iron, and manganese. Experiments were conducted at different hydraulic loadings (filtration rates) and the data was compared with experimental hydraulic conductivities (K-values) measured at various days at various filtration rates.

\section{Materials and Methods}

\section{Experimental Setup}

We used a laboratory-scale slow sand filter system with two parallel units. The filter used in the operation is of effluent-controlled and constant-flowrate type. Manometers were installed on filter walls at various depths (M1: $51 \mathrm{~cm}, \mathrm{M} 2: 44 \mathrm{~cm}, \mathrm{M} 3: 38 \mathrm{~cm}, \mathrm{M} 4: 32 \mathrm{~cm}$,

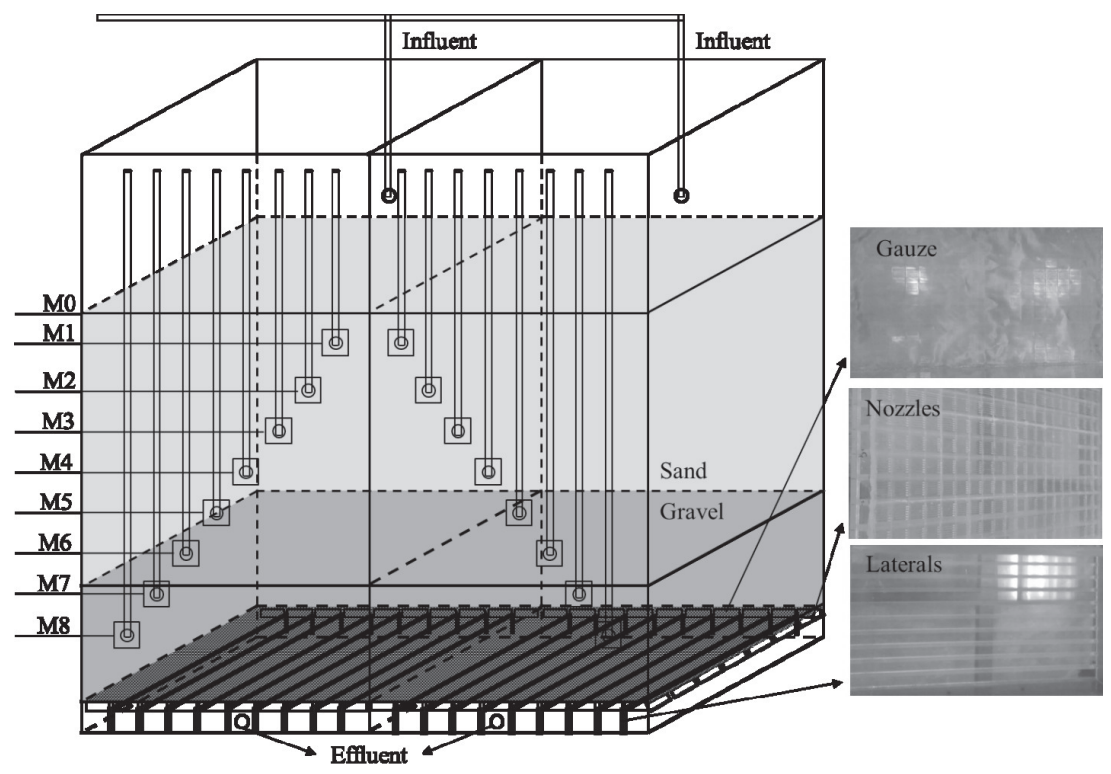

Fig. 1. Schematic view of the lab-sale slow sand filter (adapted from Manav Demir et al. [29]). 
Table 1. Dimensions of the laboratory-scale slow sand filter.

\begin{tabular}{|c|c|c|}
\hline Design parameters & Unit & Value \\
\hline Filtration rate & $\mathrm{m} / \mathrm{h}$ & $0.1-0.2-0.3$ \\
\hline Number of filter units & - & 2 \\
\hline Width of media & $\mathrm{cm}$ & 40 \\
\hline Length of media & $\mathrm{cm}$ & 60 \\
\hline Depth of media & $\mathrm{cm}$ & - \\
\hline Silica sand medium & $\mathrm{cm}$ & 37.5 \\
\hline Grading of sand - effective size & $\mathrm{mm}$ & 0.1 \\
\hline Support gravel medium & $\mathrm{cm}$ & 12.5 \\
\hline Grading of gravel & $\mathrm{mm}$ & $3-4$ \\
\hline Underdrain & $\mathrm{cm}$ & 2.5 \\
\hline Number of laterals per unit & - & 10 \\
\hline Spacing of laterals & $\mathrm{cm}$ & 3.4 \\
\hline Stainless steel gauze & $\mathrm{mesh}$ & 200 \\
\hline
\end{tabular}

M5:26 cm, M6: $20 \mathrm{~cm}, \mathrm{M} 7: 14 \mathrm{~cm}$, and M8: $8 \mathrm{~cm}$ ) for measuring headloss through the bed. The underdrain of the filters consists of the nozzles, the flow laterals, and the gauze for preventing sand particles from escaping. A schematic view of the SSF is shown in Fig. 1 and the dimensions are shown in Table 1.

The SSF was operated under 6 different conditions that include SSF1 $(0.1 \mathrm{~m} / \mathrm{h}-1 \mathrm{mg} / \mathrm{L} \mathrm{Fe}-\mathrm{Mn}), \mathrm{SSF} 2$ $(0.1 \mathrm{~m} / \mathrm{h}-2 \mathrm{mg} / \mathrm{L}$ Fe-Mn), SSF3 $(0.2 \mathrm{~m} / \mathrm{h}-1 \mathrm{mg} / \mathrm{L}$ Fe-Mn), SSF4 (0.2 m/h $-2 \mathrm{mg} / \mathrm{L} \mathrm{Fe}-\mathrm{Mn})$, SSF5 $(0.3 \mathrm{~m} / \mathrm{h}$ $-1 \mathrm{mg} / \mathrm{L} \mathrm{Fe}-\mathrm{Mn})$, and SSF6 (0.3 m/h $-2 \mathrm{mg} / \mathrm{L} \mathrm{Fe}-\mathrm{Mn})$. The experiments were conducted at room temperature. Feed water was prepared by adding iron and manganese stock solutions as well as turbidity to tap water in a mixing tank. The stock solutions were prepared daily by dissolving $\mathrm{FeSO}_{4} \cdot 7 \mathrm{H}_{2} \mathrm{O}$ and $\mathrm{MnSO}_{4} \cdot \mathrm{H}_{2} \mathrm{O}$ in deionized water.

\section{Analytical Methods}

During the study, turbidity, iron, manganese, and TOC measurements were performed in samples from different sampling ports as well as influent and effluent samples. Turbidity measurements were conducted according to the SM 2130B Nephelometric Method using WTW Turb 550 IR turbidimeter. Total iron and manganese measurements were carried out according to the SM 3111B method with AAS (Perkin Elmer Aanalyst 400 atomic absorption spectrometer) after acid digestion (Berghof Products + Instruments $\mathrm{GmbH}$ ). Turbidity, iron, and manganese measurements were performed daily in influent and effluent samples, and weekly in samples from sampling ports. Total organic carbon measurements were performed weekly according to the SM 5310B method using a TOC analyzer (HACH Lange IL 550 TOC-TN, Germany). Schmutzdecke development was determined by VS (volatile solids) analysis. For this purpose, three samples were taken randomly from the filter sand surfaces $(52.5 \mathrm{~cm})$ and different filter depths (M1: $51 \mathrm{~cm}, \mathrm{M} 2: 44 \mathrm{~cm}, \mathrm{M} 3: 38 \mathrm{~cm}, \mathrm{M} 4: 32 \mathrm{~cm}$ ) at days 30,40 , and 55. VS contents in the filter medium were determined according to method 2540G. Each analysis was performed in triplicate and reported as mean values with standard deviations.

\section{Hydraulic Conductivity}

The hydraulic conductivity of the sand medium was calculated using headlosses measured at 6 different depths of the bed, which should be calculated by using at least 3 measurements at different depths [29]. The K-values were calculated using the well-known Darcy's law as follows:

$$
K=\frac{Q * L}{A * \Delta h}
$$

...where $K$ is hydraulic conductivity $(\mathrm{m} / \mathrm{s}), Q$ is the filter flowrate $\left(\mathrm{m}^{3} / \mathrm{s}\right), L$ is depth of the manometer port from surface (m), $A$ is the cross-sectional area of the filter bed $\left(\mathrm{m}^{2}\right)$, and $\Delta h$ is the measured headloss at the given manometer port (measured as the difference between hydraulic heads) (m).

\section{Results and Discussion}

In the previous study, a laboratory-scale slow sand filter (SSF) system was used to investigate turbidity, iron, and manganese removal under different operating conditions. In our previous studies [16, 30], turbidity removal efficiencies were calculated as $94.8 \pm 2.80 \%$, $95.9 \pm 2.60 \%, 96.3 \pm 2.4 \%, 97.9 \pm 1.3 \%, 97.7 \pm 0.83 \%$, and $98.2 \pm 0.79 \%$. Iron removal efficiencies achieved in SSF1, SSF2, SSF3, SSF4, SSF5, and SSF6 runs were calculated as $90.4 \pm 4.80 \%, 94.4 \pm 3.20 \%, 92.3 \pm 6.06 \%, 93.1 \pm 8.11 \%$, $93.4 \pm 4.40 \%$, and $95.4 \pm 4.80 \%$, respectively. Manganese removal efficiencies were calculated as $90.3 \pm 5.80 \%$, $95.4 \pm 5.20 \%, 92.7 \pm 5.7 \%, 94.3 \pm 5.7 \%, 94.9 \pm 6.14 \%$, and $95.9 \pm 3.50 \%$, respectively, in SSF1, SSF2, SSF3, SSF4, SSF, and SSF6. In this study, the SSF system was used to investigate biomass formation in different depths of SSF depending on various operating conditions in regard to filtration rate and influent iron-manganese concentrations.

\section{Iron, Manganese, and Turbidity Removal}

Samples were taken from different bed depths (M1: $51 \mathrm{~cm}, \mathrm{M} 2: 44 \mathrm{~cm}, \mathrm{M} 3: 38 \mathrm{~cm}, \mathrm{M} 4: 32 \mathrm{~cm}, \mathrm{M} 5$ : $26 \mathrm{~cm}$, M6: $20 \mathrm{~cm}, \mathrm{M7}: 14 \mathrm{~cm}$, and M8: $8 \mathrm{~cm}$ ) at various days starting from day 30 for turbidity, iron, and manganese measurements. Average removal efficiencies calculated using influent turbidity, iron, and manganese concentrations are shown in Fig. 2.

For SSF1, average turbidity, iron, and manganese removal efficiencies at the uppermost layer (within $1.5 \mathrm{~cm}$ 

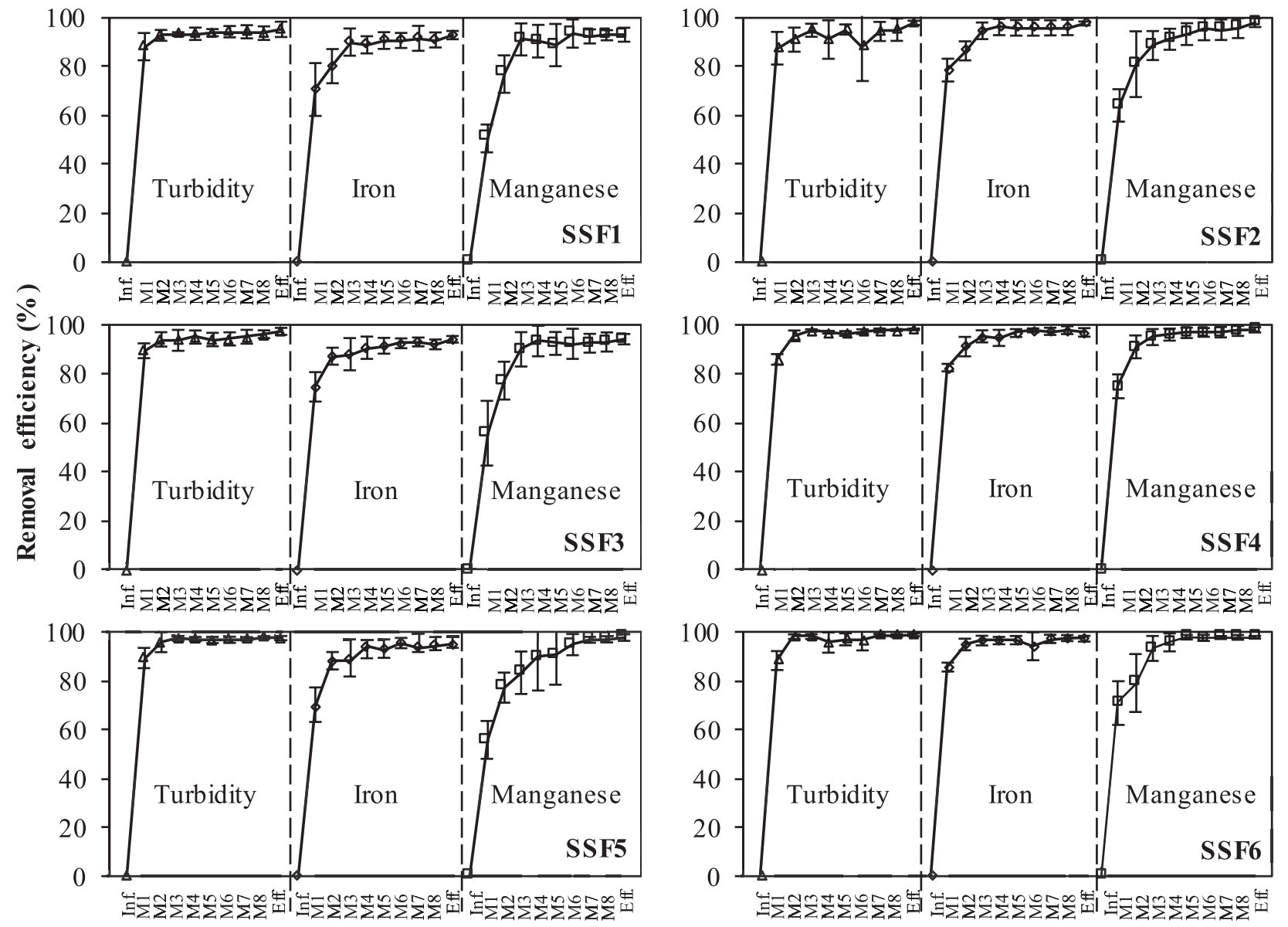

Manometers

Fig. 2. Iron, manganese, and turbidity removal efficiencies along the depth of the filter bed for all operating conditions.

between the surface and M1: $51 \mathrm{~cm}$ ) were calculated as $88.2 \pm 5.6 \%, 70.7 \pm 10.8 \%$, and $50.7 \pm 5.7 \%$, respectively. At the first two layers (within $8.5 \mathrm{~cm}$ between the surface and M2: $44 \mathrm{~cm}$ ), cumulative removal efficiencies increased to $92.8 \pm 2.2 \%, 80.2 \pm 7.0 \%$, and $76.9 \pm 7.7 \%$, respectively for turbidity, iron, and manganese. The third layer (between M2: $44 \mathrm{~cm}$ and M3: $38 \mathrm{~cm}$ ) also contributed to turbidity, iron, and manganese removal. Cumulative removal efficiencies at the bottom of the third layer (within $14.5 \mathrm{~cm}$ between the surface and M3: $38 \mathrm{~cm}$ ) were calculated as $93.3 \pm 0.8 \%, 90.1 \pm 5.6 \%$, and $91.2 \pm 6.6 \%$, respectively, for turbidity, iron, and manganese. No significant changes were observed at lower layers of the filter bed.

Similar trends were observed for all operating conditions (Fig. 2) in regard to turbidity, iron, and manganese removal. For all operating conditions, it is possible to conclude that most turbidity, iron, and manganese removal take place within the first layer of the filter bed $(1.5 \mathrm{~cm}$ from the surface), and the second and the third layers (until about $15 \mathrm{~cm}$ from the surface) also contribute to treatment efficiency, while removal within lower layers is negligible in comparison. Similar results were reported in a secondary rapid sand filter for iron, manganese, and ammonium removal, where iron concentrations decreased quickly in the first $30 \mathrm{~cm}$ of bed depth and manganese penetrated to the first $70 \mathrm{~cm}$ [31]. Hoyland et al. [32] reported manganese removal in a laboratory-scale biologically active column filter, in which manganese removal efficiency was found as $80 \%$ at $13 \mathrm{~cm}$ of bed depth and $100 \%$ at $20 \mathrm{~cm}$. In another study aimed at iron, manganese, and ammonia removal, Li et al. [33] reported that the abundance of Gallionella decreased from $26.0 \%$ (20 cm depth) to $16.1 \%$ (40 cm depth) and to $0 \%$ (60 cm depth). Results of Cheng et al. [34] and Yang et al. [35] also suggest that iron is quickly removed from water within the first few centimeters of the filter bed while manganese can penetrate deeper. Results of this study agree well with literature [31-35]. It can be concluded that iron removal in sand filtration is completed within the first few centimeters of the filter bed. For manganese, the removal efficiency always stays lower compared to iron removal efficiency, and manganese can easily penetrate deeper within the bed.

In addition to removal efficiencies at depths of the filter bed, average unit removals ( $\partial \eta / \partial H$ values) in the first three layers were also calculated as removal efficiencies per unit bed depth. Values of $\partial \eta / \partial H$ could give idea about the biofilm accumulation in these layers and could be used as a measure of the intensity of schmutzdecke development. Calculated $\partial \eta / \partial H$ values are shown in Table 2. Most of the turbidity removal takes place within the first layer of 
Table 2. Calculated unit removal efficiencies in the first 3 layers of the filter bed.

\begin{tabular}{|c|c|c|c|c|c|c|c|}
\hline \multirow{2}{*}{ Species } & \multirow{2}{*}{ Layers* } & \multicolumn{6}{|c|}{ Operating conditions } \\
\hline & & SSF1 & SSF2 & SSF3 & SSF4 & SSF5 & SSF6 \\
\hline \multirow{3}{*}{$\begin{array}{l}\text { Turbidity } \\
\text { removal }\end{array}$} & Layer 1 & 58.8 & 58.4 & 59.6 & 57.3 & 59.5 & 58.9 \\
\hline & Layer 2 & 0.66 & 0.50 & 0.67 & 1.37 & 0.93 & 1.39 \\
\hline & Layer 3 & 0.08 & 0.63 & 0.10 & 0.37 & 0.25 & 0.02 \\
\hline \multirow{3}{*}{$\begin{array}{l}\text { Iron } \\
\text { removal }\end{array}$} & Layer 1 & 47.1 & 52.4 & 49.7 & 55.0 & 46.1 & 57.1 \\
\hline & Layer 2 & 1.36 & 1.13 & 1.80 & 1.23 & 2.70 & 1.31 \\
\hline & Layer 3 & 1.65 & 1.30 & 0.13 & 0.70 & 0.03 & 0.27 \\
\hline \multirow{3}{*}{$\begin{array}{c}\text { Manganese } \\
\text { removal }\end{array}$} & Layer 1 & 33.8 & 42.8 & 37.1 & 49.9 & 37.2 & 47.3 \\
\hline & Layer 2 & 3.74 & 2.40 & 3.07 & 2.29 & 3.06 & 1.17 \\
\hline & Layer 3 & 2.38 & 1.28 & 2.12 & 0.67 & 1.02 & 2.35 \\
\hline
\end{tabular}

Layer 1: Between the surface and M1: $51 \mathrm{~cm}$

Layer 2: Between M1: $51 \mathrm{~cm}$ and M2: $44 \mathrm{~cm}$

Layer 3: Between M2: $44 \mathrm{~cm}$ and M3: $38 \mathrm{~cm}$

the filter bed for all operating conditions. Unit turbidity removals were very close to each other, meaning that turbidity removal is independent of operating conditions (filtration rate), which agrees with the findings in [16]. However, a certain slight decrease in unit turbidity removal in the first layer was observed with increasing iron and manganese concentrations (SSF1-SSF2 pairs, SSF3-SSF4 pairs, and SSF5-SSF6 pairs).

Unit iron removals in the first three layers were always less than unit turbidity removals for all operating conditions (Table 2). Most of the iron removal took place in the first layer, while the second and the third layers contributed slightly to iron removal. One should note that unit iron removal in the first layer increased by about $5 \%$ per centimeter with increasing influent ironmanganese concentrations at filtration rates of 0.1 (SSF1 and SSF2) and $0.2 \mathrm{~m} / \mathrm{h}$ (SSF3 and SSF4). The change in unit iron removal was about $10 \%$ when influent ironmanganese concentrations were increased by two-fold at $0.3 \mathrm{~m} / \mathrm{h}$ (SSF6). Also, unit iron removal showed a clear dependency on filtration rate. At constant influent ironmanganese concentrations, unit iron removal in the first layer increased with increasing filtration rates. The unit iron removal showed different behavior in the second and the third layers.

Unit manganese removals in the first layer were less than the unit iron removals in the same layer for all operating conditions, while higher unit manganese removals were observed in the second and the third layers. Similar to unit iron removals, unit manganese removal was also a function of filtration rate. Unit manganese removal increased as the filtration rate increased. In the second and the third layers, the contribution to manganese removal was inversely proportional to the unit manganese removal in the first layer, e.g., unit manganese removal in the second and the third layer decreased with increasing influent concentrations of iron and manganese. One final note on unit iron and manganese removals is that unit manganese removals in the first layer were always 5 to $13 \%$ less than unit iron removals for all operating conditions, meaning that manganese can penetrate deeper in the filter bed because of the fact that the rate of manganese oxidation by microorganisms in schmutzdecke is lower compared to that of iron oxidation.

\section{Total Organic Carbon Removal}

Total organic carbon (TOC) removal performances of the SSFs were also evaluated under all operating conditions. Influent and effluent samples were collected at various days of operation during the study. Average influent TOC concentrations were measured as $3.63 \pm 0.3,3.40 \pm 0.2,3.25 \pm 0.3,3.36 \pm 0.3,3.51 \pm 0.3$, and $3.50 \pm 0.3 \mathrm{mg} / \mathrm{L}$, respectively, for SSF1, SSF2, SSF3, SSF4, SSF5, and SSF6, while average effluent concentrations were $1.73 \pm 0.16,1.71 \pm 0.18,1.44 \pm 0.2,1.49 \pm 0.3,1.68 \pm 0.1$, and $1.48 \pm 0.3 \mathrm{mg} / \mathrm{L}$, respectively. The TOC removal efficiencies obtained for all operating conditions were $52.3 \pm 3.6 \%, 49.3 \pm 5.8 \%, 55.3 \pm 8.3 \%$ [29], $55.5 \pm 6.8 \%$ [30], $52.0 \pm 4.8 \%$, and $57.6 \pm 8.2 \%$, respectively. Results at various days of operation for all operating conditions are shown in Fig. 3. Results showed that TOC removal efficiency increases with time. Although negligible changes were observed depending on operating conditions, the highest average TOC removal efficiencies were observed at a filtration rate of $0.3 \mathrm{~m} / \mathrm{h}$ and influent iron-manganese concentrations of $2 \mathrm{mg} / \mathrm{L}$ (SSF6).

Grace et al. [2] used synthetic water to determine the performance of the slow sand filter with $0.1 \mathrm{~m} / \mathrm{h}$ filtration rate for two different operating schemes (continuous loading and intermittent loading). They found that dissolved organic carbon (DOC) removal efficiencies for continuous loading and intermittent loading were 
$16.7 \pm 3.3 \%$ and $24.3 \pm 2.5 \%$, respectively (influent DOC concentration $5.7 \pm 2.2$ and $6 \pm 1.7 \mathrm{mg} / \mathrm{L}$, respectively). Aydin [36] determined the TOC removal efficiency as $59.4 \%$ during the treatment of stream water with TOC concentration of $6.7 \mathrm{mg} / \mathrm{L}$ with slow sand filter (filtration rate was $0.1 \mathrm{~m} / \mathrm{h}$ ). Bar-Zeev et al. [37] studied the treatment of seawater using a single-medium rapid sand filter and found TOC removal efficiencies of $17 \%, 37 \%$, and $55 \%$ on days 7,27 , and 42 , respectively. Linlin et al. [38] found that the average DOC in slow sand filtration decreased from $6.3 \pm 1.3 \mathrm{mg} / \mathrm{L}$ to $2.6 \pm 0.8 \mathrm{mg} / \mathrm{L}$ in the $\mathrm{O}_{3} / \mathrm{SSF} / \mathrm{NF}$ combination process study (removal efficiency 58.7\%). Zheng et al. [39] used Ruhleben WWTP secondary effluent in their studies. They found TOC removal efficiencies of $10.3 \%$ and $9.4 \%$, respectively, with slow sand filtration at $0.25 \mathrm{~m} / \mathrm{h}$ and $0.5 \mathrm{~m} / \mathrm{h}$. Jin et al. [40] used slow sand filtration for the treatment of Saugeen River water and found DOC removal efficiencies of around $30-40 \%$. Results from the current study agree with the findings of previous researchers.

\section{Biofilm Formation}

Schmutzdecke is a biologically active layer of organic matter that allows growth of a consortium of microorganisms depending on influent water characterization [11], and that develops mainly within the upper few centimeters of the sand bed in SSFs $[5,20]$. Since the investigation of the development of schmutzdecke is the main topic of this study, a number of
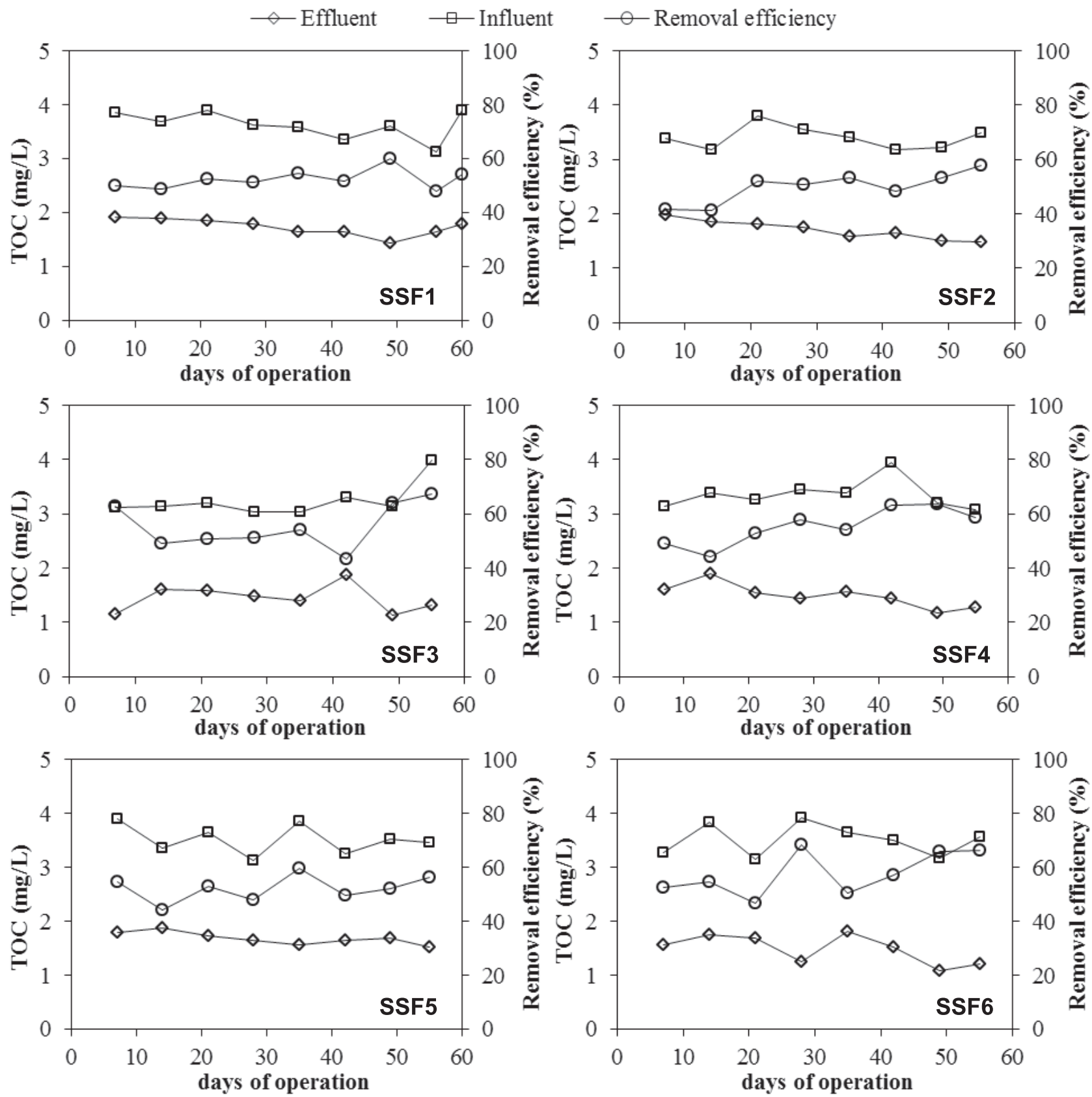

Fig. 3. The influent and effluent TOC concentrations and removal efficiencies for each filter. 
bed samples for each operating condition from the surface (M0: $52.5 \mathrm{~cm}$ ) and four depths (M1: $51 \mathrm{~cm}, \mathrm{M} 2: 44 \mathrm{~cm}$, M3: $38 \mathrm{~cm}$, and M4: $32 \mathrm{~cm}$ ) were collected at various days of operation (30, 45, and 55). VS analyses were performed on the samples (Fig. 4). The highest VS concentrations on the surface (M0: $52.5 \mathrm{~cm}$ ) were determined on the last day of operation as $9.05 \pm 0.12,11.71 \pm 0.03,11.21 \pm 0.10$, $12.62 \pm 0.01,13.66 \pm 0.05$, and $16.93 \pm 0.07 \mathrm{mgVS} / \mathrm{g}$ dry sand, respectively, for SSF1, SSF2, SSF3, SSF4, SSF5, and SSF6. At M1: $51 \mathrm{~cm}$, the VS concentrations dropped to $4.23 \pm 0.10,4.82 \pm 0.09,4.33 \pm 0.20,4.86 \pm 0.10,5.39 \pm 0.04$, and $5.59 \pm 0.19 \mathrm{mgVS} / \mathrm{g}$ dry sand, respectively, for SSF1,
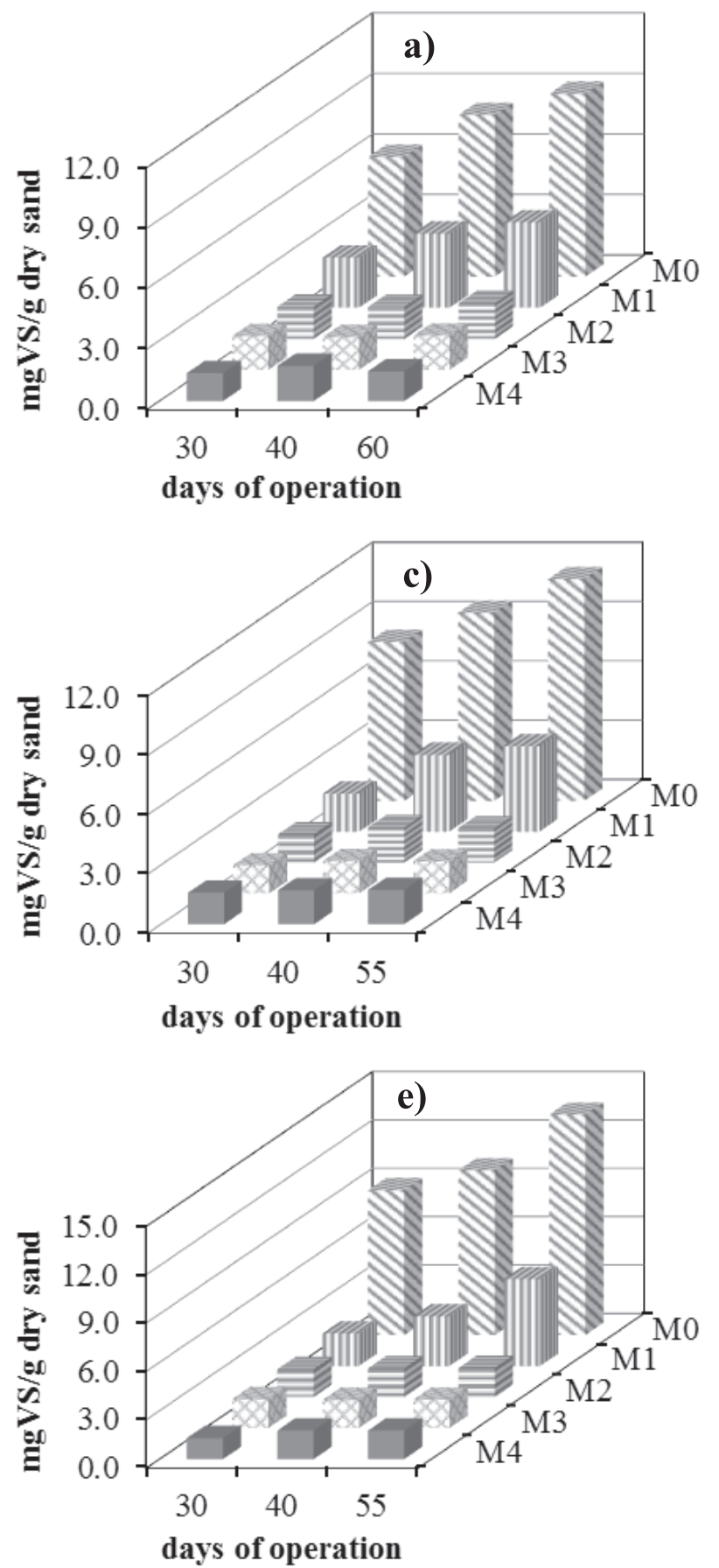

SSF2, SSF3, SSF4, SSF5, and SSF6. At the lower levels (M2: $44 \mathrm{~cm}, \mathrm{M} 3: 38 \mathrm{~cm}$, and M4: $32 \mathrm{~cm}$ ), the VS concentrations were very close to each other, and no significant differences from the initial VS concentrations were observed in these layers, which shows that the schmutzdecke layer is mainly formed on the filter surface and decreases along the filter bed.

Li et al. [33] reported that the bacterial concentrations fall very quickly along with the depth of the filter bed due to substrate and oxygen deficiency. In another study, Campos et al. [14] investigated total microbial biomass concentration as sand biomass. They reported that the
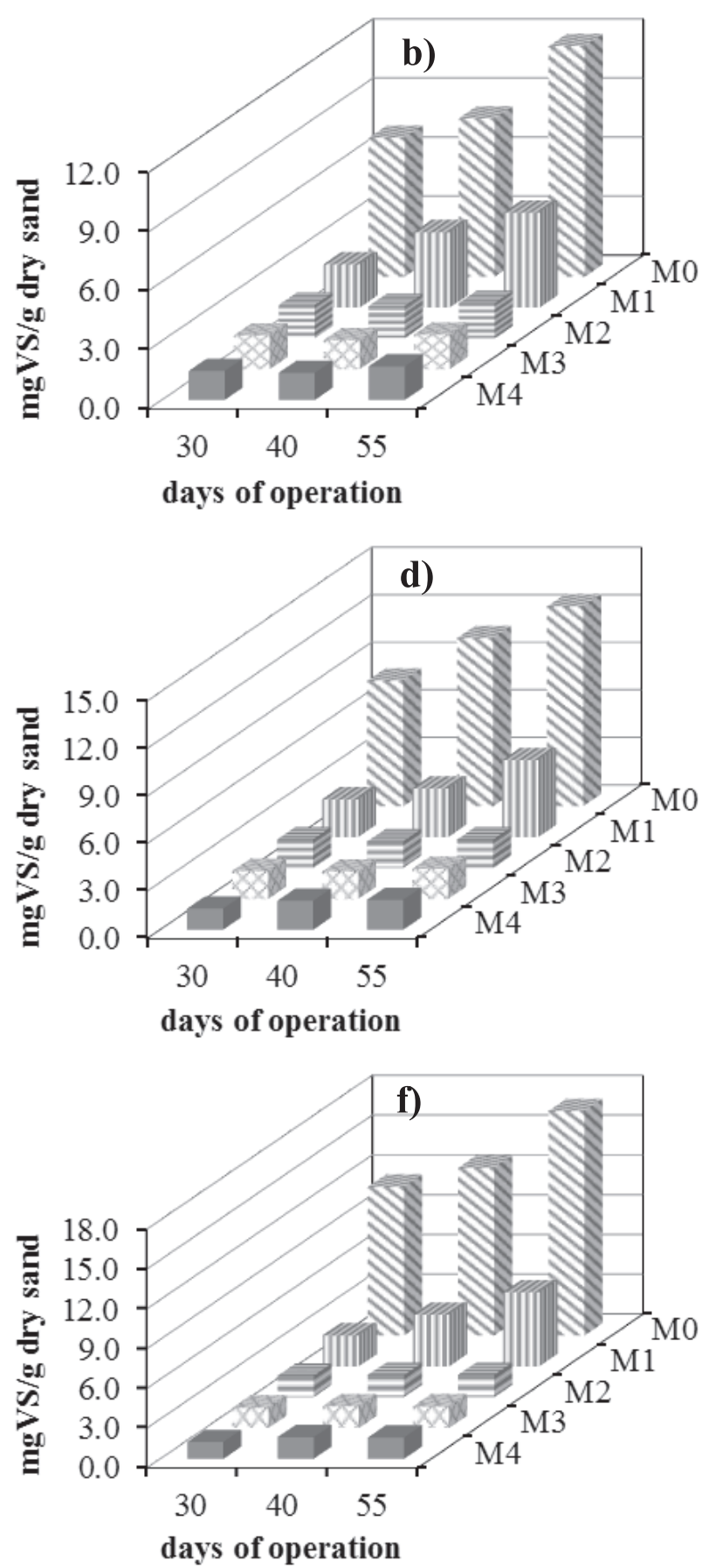

Fig. 4. Volatile solids (VS) results for each filter: a) SSF1, b) SSF2, c) SSF3, d) SSF4, e) SSF5, and f) SSF6. 
biomass concentration decreased quickly with filter depth, that biomass formation was mainly observed in the top $2 \mathrm{~cm}$ of the filter bed, and that biomass concentration in the top $2 \mathrm{~cm}$ of filter bed was $120 \mu \mathrm{g} \mathrm{C} / \mathrm{g}$ dry sand on day 56. Pompei et al. [4] reported similar results as 46.45 and $94.96 \mu \mathrm{g} \mathrm{C} / \mathrm{g}$ dry sand in a slow sand filter for household water purification. Grace et al. [2] pointed out that filter clogging was mainly caused by a layer of organic material in both continuous and intermittent operation, and that higher organic matter accumulation occurs on the surface. In addition, biomass concentrations were measured as 40, 12, and $7 \mathrm{mg}$ biomass per gram sand in upper, middle, and lower layers of a filter for treating microcystin analogues, in which total bed depth was $15 \mathrm{~cm}$ and the biomass concentration in clean sand was measured as $5 \mathrm{mg}$ biomass per gram sand [41]. Results from Ho et al. [41] also suggest that biomass formation takes place mainly in the top layer of the sand bed and decreases quickly with bed depth. Results from this study agree well with literature data.

\section{Hydraulic Conductivity}

Hydraulic conductivity ( $\mathrm{K}$-value) is a measure of clogging of the filter bed, with reduced K-values meaning the clogging of the bed. Hydraulic conductivities of the
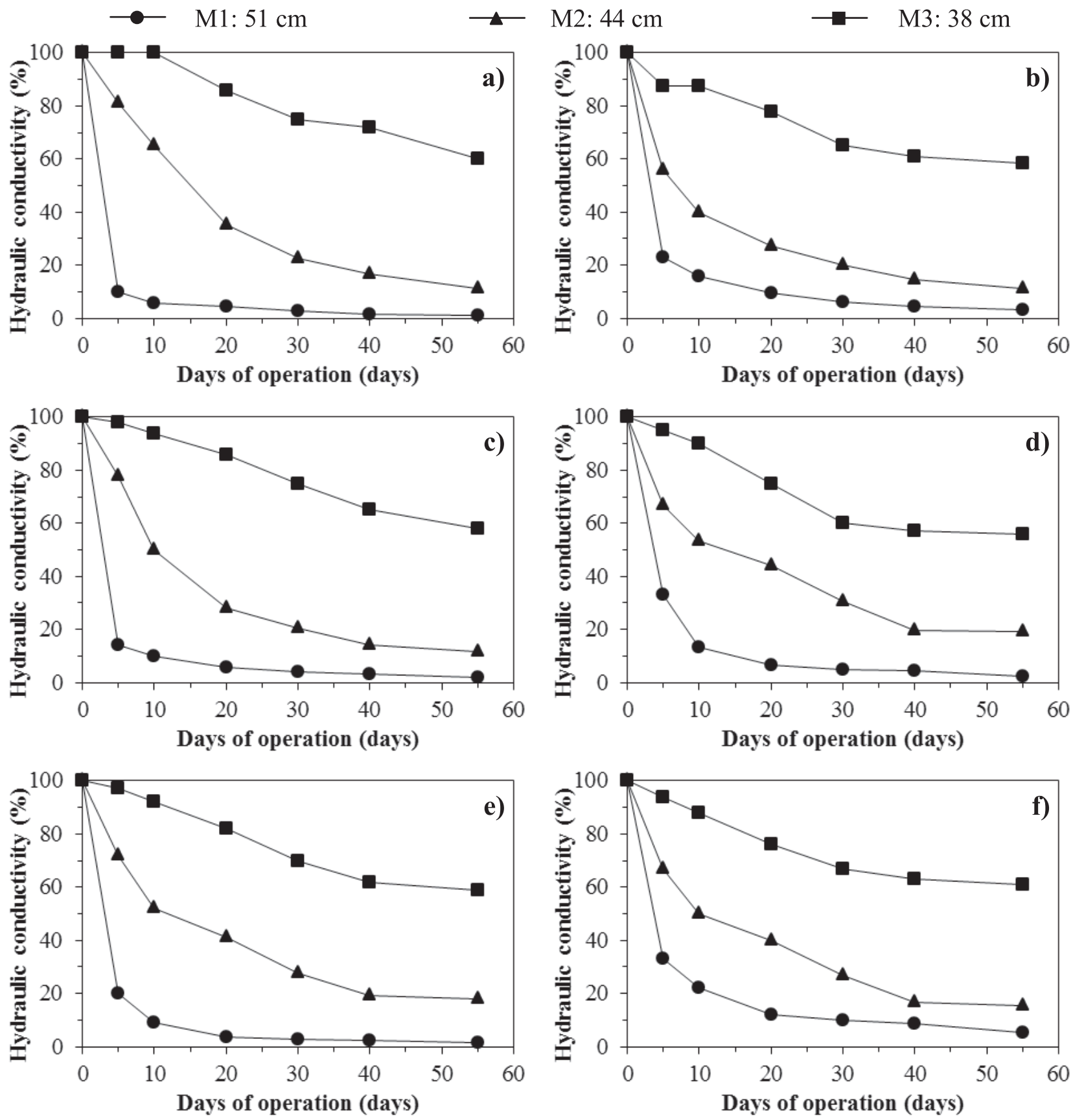

Fig. 5. Hydraulic conductivities in the first three layers (M1:51 cm, M2: $44 \mathrm{~cm}$, and M3: $38 \mathrm{~cm}$ ) during the operation of a) SSF1, b) SSF2, c) SSF3, d) SSF4, e) SSF5, and f) SSF6. 
filter bed at various days of operation for each operating condition were calculated using headloss measurements taken at various depths (M1: $51 \mathrm{~cm}, \mathrm{M} 2: 44 \mathrm{~cm}, \mathrm{M} 3$ : $38 \mathrm{~cm}, \mathrm{M} 4: 32 \mathrm{~cm}, \mathrm{M}$ : $26 \mathrm{~cm}, \mathrm{M} 6: 20 \mathrm{~cm}$ ) during the filter operation (initial and days 5, 10, 20, 30, 40, and 55). Since the biofilm formation takes place at the top layer of the filter bed and the conductivity is a measure of biofilm formation, K-value changes along the filter depth during the whole operation and weighted averages of K-values over all depths were calculated. The calculated averages decreased continuously during the operation. The highest initial value of hydraulic conductivity (as a weighted average) was calculated as $13.7 \mu \mathrm{m} / \mathrm{s}$, while the lowest values ranged from 3.28 to $6.62 \mu \mathrm{m} / \mathrm{s}$ (as weighted average) at the end of 55 days of operation.

Hydraulic conductivities of various layers of the filter bed were calculated. Calculations were performed separately for each operating condition. In order to monitor the formation of biofilm (identified by the decrease in $\mathrm{K}$-value), the initial value of hydraulic conductivity in each operating condition is assumed as $100 \%$, and the $\mathrm{K}$-values during the operation were reported as a percent of initial. Since there is no evidence of biofilm formation in lower layers of the bed, hydraulic conductivities calculated for only the first three layers $(\mathrm{M} 1: 51 \mathrm{~cm}, \mathrm{M} 2$ : $44 \mathrm{~cm}, \mathrm{M} 3: 38 \mathrm{~cm}$ ) are reported here. Results are shown in Fig. 5.

The change of hydraulic conductivities with respect to time showed similar patterns in all operating conditions. A sharp decrease of K-value after the first five days of operation was observed in all operating conditions. In this period, the K-values in the first layer dropped to around $10 \%$ to $33.3 \%$ of initial. The rate of decrease in hydraulic conductivity slowed down and the K-value became more or less stabilized after 20 days of operation. The hydraulic conductivities in the first layer were stabilized at values ranging from $1.2 \%$ to $5.3 \%$ of initial at the end of operation (55 days). This means that clogging in the first layer was severe at the end of the operation in all operating conditions.

In the second layer (between M1: $51 \mathrm{~cm}$ and M2: $44 \mathrm{~cm}$ ), simultaneous decreasing trends were observed along with the first layer. However, the slopes of decrease in hydraulic conductivity were milder in the first five days compared to that in the first layer of the same operating condition. Between days 5 and 20 the K-values dropped rapidly to $27.5 \%$ to $44 \%$ of initial in all operating conditions. At the end of day 55 the hydraulic conductivities became stabilized at values ranging $11.1-19.0 \%$. This means that the solids mostly penetrated to the second layer.

In the third layer (between M2: $44 \mathrm{~cm}$ and M3: $38 \mathrm{~cm})$, the K-values stayed nearly constant at around $90 \%$ to $100 \%$ of initial during the first 10 days of operation. After 10 days, solids started penetrating to the third layer. However, penetration was limited due to the effect of filtration in the first 2 layers and the final $\mathrm{K}$-values in the third layer were as high as $60 \%$ of initial at the end of operation (55 days).
Btatkeu-K et al. [27] performed similar experiments with metallic iron-sand filter $50 \mathrm{~cm}$ in height and $2.6 \mathrm{~cm}$ in diameter, in which they found that the hydraulic conductivity of the filter bed was reduced by $80 \%$ on day 12 . They also reported that, after 50 days of operation, hydraulic conductivity was reduced by almost $100 \%$ in the pure $\mathrm{Fe}^{0}$ bed. In another study, Lynn et al. [25] reported that hydraulic conductivity dropped to $40 \%$ of its initial value after 107 days of operation. Results from this study agree with reported values.

The hydraulic conductivities in lower layers stayed nearly constant at around $100 \%$ of initial during the filter operation in all operating conditions, which means that the microbial growth was limited in these layers. The pattern of K-values with respect to time showed slight changes depending on operating conditions. At the same filtration rate $(0.1 \mathrm{~m} / \mathrm{h})$, the decrease in $\mathrm{K}$-value of the first layer in SSF1 (10\% of initial) was sharper compared to that in SSF2 $(23.1 \%$ of initial). Similar trends were observed between SSF3 and SSF4 as well as SSF5 and SSF6. The results suggest that the rate of decrease in hydraulic conductivity is a function of influent iron and manganese concentrations and that the rate decreases with increasing influent concentration. Depending on the rate of filtration with the same influent ironmanganese concentration, the rate of decrease in hydraulic conductivity (the rate of solids accumulation/ biofilm formation) increases with increasing filtration rate.

\section{Conclusions}

A laboratory-scale slow sand filtration system was used to investigate the biofilm formation depending on operating conditions and time. The system was operated under six different operating conditions based on the rate of filtration and influent iron-manganese concentrations. The system was operated 55 days for all operating conditions and samples were collected at various depths of the filter bed for measuring iron and manganese concentrations as well as turbidity. Besides, influent and effluent TOC concentrations were monitored. In addition, bed samples were collected from various depths at various days of operation and volatile solids measurements were performed. Finally, headloss measurements were conducted at various depths of filter bed and hydraulic conductivities of different layers of the bed were calculated. The following conclusions can be drawn from the results of this study:

- Most turbidity, iron, and manganese removal takes place within the first few centimeters at the top of the filter bed. Iron concentration and turbidity quickly decrease in this layer while manganese can penetrate deeper in the bed.

- Unit removal efficiencies at the uppermost layer of the filter bed can be as high as $59.5 \%, 55.0 \%$, and $49.9 \%$ per centimeter of bed depth, respectively, for turbidity, iron, and manganese. Considering the 
biofilm formation in this layer, schmutzdecke greatly affects iron and manganese removal.

- Increasing influent iron and manganese concentration results in a clear increase in unit iron and manganese removal efficiencies, while the effect on filtration rate is negligible.

- Total organic carbon (TOC) removal efficiencies can be as high as $57.6 \%$, although filtration rate and influent concentrations of iron, manganese, and TOC do not affect removal efficiency at all.

- VS concentrations in the filter bed can be used as a measure of schmutzdecke formation. According to this, a fully developed schmutzdecke is formed in the uppermost layer of the filter bed. Decreasing VS concentrations in lower layers indicates that microbial activity decreases with bed depth. The intensity of schmutzdecke formation depends on the rate of filtration as well as influent ironmanganese concentrations. Higher filtration rates and higher influent concentrations result in higher VS concentrations in the upper layers of the bed.

- Hydraulic conductivity (K-value) is also a good measure of schmutzdecke formation. Hydraulic conductivity of the filter bed decreases with time as biofilm formation in the upper layers of the bed take place. Sharp decreases in K-values in the upper two layers indicate that biofilm formation in these layers is the most intense. Although part of solids also penetrate into a few centimeters from the surface, no significant changes occur in lower layers of the bed where microbial growth is limited.

\section{Acknowledgements}

This research has been supported by Y1ld1z Technical University Scientific Research Projects Coordination Department (project No. 2014-05-02-GEP01).

\section{References}

1. ÖZER S., YILDIZ S., KARAKUS C.B. Comparison of manganese removal efficiency for kaloratory and plant scale in Sivas 4 Eylül Dam potable water. J. Fac. Eng. Arch. Selcuk Univ. 26 (1), 1, 2011.

2. GRACE M.A., HEALY M.G., CLIFFORD E. Performance and surface clogging in intermittently loaded and slow sand filters containing novel media. J. Environ. Manage. 180, 102, 2016.

3. GUCHI, E. Review on slow sand filtration in removing microbial contamination and particles from drinking water. American Journal of Food and Nutrition 3 (2), 47, 2015.

4. POMPEI C.M.E., CIRIC L., CANALES M., KARU K., VIEIRA E.M., CAMPOS L.C. Influence of PPCPs on the performance of intermittently operated slow sand filters for household water purification. Sci. Total Environ. 581-582, 174, 2017.
5. OKI L.R., BOGAGHI S., LEE E., HAVER D., PITTON B., NACKLEY L., MATHEWS D.M. Elimination of Tobacco mosaic virus from irrigation runoff using slow sand filtration. Sci. Hortic-Amsterdam. 217, 107, 2017.

6. RAMADAN M. Efficiency of new Miswak, titanium dioxide and sand filters in reducing pollutants from wastewater. Beni - Suef University Journal of Basic and Applied Sciences. 4, 47, 2015.

7. LAUTENSCHLAGER K., HWANG C., LING F., LIU W-T., BOON N., KOSTER O., EGLI T., HAMMES F. Abundance and composition of indigenous bacterial communities in a multi-step biofiltration-based drinking water treatment plant. Water Res. 62, 40, 2014.

8. LEE E., OKI L.R. Slow sand filters effectively reduce Phytophthora after a pathogen switch from Fusarium and a simulated pump failure. Water Res. 47, 5121, 2013.

9. MWAKABONA H.T., NDE-TCHOUPE A.I., NJAU K.N., NOUBACTEP C., WYDRA K.D. Metallic iron for safe drinking water provision: Considering a lost knowledge. Water Res. 117, 127, 2017.

10. SCHOLZ M. Chapter 10: Slow Filtration. Wetlands for Water Pollution Control (Second Edition); Publisher: Elsevier Ltd., USA, 61, 2016.

11. ÖSTERDAHL M. Slow sand filtration as a water treatment method - An inventorying study of slow sand filters purification rates in rural areas in Colombia. Bachelor Thesis, Bachelor of Science in Environmental and Energy Engineering, Karlstads University, Sweden, 2015.

12. SEEGER E.M., BRAECKEVELT M., REICHE N., MULLER J.A., KASTNER M. Removal of pathogen indicators from secondary effluent using slow sand filtration: Optimization approaches. Ecol. Eng. 95, 635, 2016.

13. SCHIJVEN J.F., VAN DEN BERG H.H.J.L., COLIN M., DULLEMONT Y., HIJNEN W.A.M., MAGICKNEZEV A., OORTHUIZEN W.A., WUBBELS G. A mathematical model for removal of human pathogenic viruses and bacteria by slow sand filtration under variable operational conditions. Water Res. 47, 2592, 2013.

14. CAMPOS L.C., SU M.F.J., GRAHAM N.J.D., SMITH S.R. Biomass development in slow sand filters. Water Res. 36, 4543, 2002.

15. BRANDT M.J., JOHNSON K.M., ELPHINSTON A.J., RATNAYAKA D.D. Chapter 9: Water Filtration. Twort's Water Supply (Seventh Edition); Publisher: Elsevier Ltd., USA, 367, 2017.

16. MANAV DEMIR N. Experimental Study of Factors that Affect Iron and Manganese Removal in Slow Sand Filters and Identification of Responsible Microbial Species. Pol. J. Environ. Stud. 25 (4), 1453, 2016.

17. LAW S.P., MELVIN M.M.A.L., LAMB A.J. Visualisation of the establishment of a heterotrophic biofilm within the schmutzdecke of a slow sand filter using scanning electron microscopy. Biofilm Journal. 
6 (1), 2001. Available online: http://www.bioline.org. br/request?bf01001 (accessed on 07 July 2017).

18. TYAGI V.K., KHAN A.A., KAZMI A.A., MEHROTRA I., CHOPRA A.K. Slow sand filtration of UASB reactor effluent: A promising post treatment technique. Desalination. 249, 571, 2009.

19. GRAHAM N.J.D., COLLINS M.R. Chapter 1: Slow sand filtration: recent research and application perspectives. Progress in Slow Sand and Alternative Biofiltration Processes Further Developments and Applications, Part I General Overview. IWA Publishing, UK, pp. 3-16, 2014. Available online: https://books.google.com.tr/books?id=mbgDBAAAQ BAJ\&pg $=$ PA3\&lpg $=$ PA $3 \&$ dq $=$ slow + sand + filtration $:+$ recent + research + and + application + perspectives \& source=bl\&ots=V_GWU4Rt39\&sig=8Hax_U6tFB WDXE_afvn2bIlY $\overline{d g} \& \mathrm{hl}=\operatorname{tr} \& s a=X \& v e d=0 \overline{a h U K E W}$ jF_P2JqKXUAhUEfywKHf8kBEYQ6AEIODAB\# $\mathrm{v}=$ onepage \& $\mathrm{q}=$ slow $\% 20$ sand $\% 20$ filtration $\% 3 \mathrm{~A} \% 20$ recent $\% 20$ research $\% 20$ and $\% 20$ application $\% 20$ perspectives \&f=false (accessed on 07 July 201).

20. LIVINGSTON P.A. Management of the schmutzdecke layer of a slow sand filter. Doctor of Philosophy, The University of Arizona, 2013. Available online: http:// hdl.handle.net/10150/293439 (accessed on 07 July 2017).

21. JOUBERT E.D., PILLAY B. Visualisation of the microbial colonization of a slow sand filter using an Environmental Scanning Electron Microscope. Electron. J. Biotechn. 11 (2), 1, 2008.

22. LI Z., HASSAN A.A., SAHLE-DEMESSIE E., SORIAL G.A. Transport of nanoparticles with dispersant through biofilm coated drinking water sand filters. Water Res. 47, 6457, 2013.

23. CAMPOS L.C., SMITH S.R., GRAHAM N.J.D. Deterministic-Based model of slow sand filtration. I: Model development. J. Environ. Eng-ASCE. 132 (8), 872, 2006.

24. CAMPOS L.C., SMITH S.R., GRAHAM N.J.D. Deterministic-Based model of slow sand filtration. II: Model application. J. Environ. Eng-ASCE. 132 (8), $887,2006$.

25. LYNN T.J., WANJUGI P., HARWOOD V.J., ERGAS S.J. Dynamic performance of biosand filters. J. Am. Water Works Ass. 2013. Available online: http:// dx.doi.org/10.5942/jawwa.2013.105.0116 (accessed on 07 July 2017).

26. OOSTERBAAN R.J., NIJLAND H.J. Determining the saturated hydraulic conductivity. Chapter 12 in: H.P.Ritzema (Ed.), Drainage Principles and Applications. International Institute for Land Reclamation and Improvement ( ILRI), Publication 16, second revised edition, Wageningen, The Netherlands, 1994. Available online: https://www.waterlog.info/ pdf/chap12.pdf (accessed on 07 July 2017).

27. BTATKEU-K B.D., OLVERA-VARGAS H., TCHATCHUENG J.B., NOUBACTEP C., CARE S. Determining the optimum $\mathrm{Fe}^{0}$ ratio for sustainable granular $\mathrm{Fe}^{0} /$ sand water filters. Chem. Eng. J. 247, 265, 2014.
28. BARRETT J.M., BRYCK J., COLLINS M.R., JANONIS B.A., LOGSDON G.S. Manual of Design for Slow Sand Filtration. AWWA Research Foundation and American Water Works Association, U.S.A, 1991. Available online: http://protosh2o.act. be/VIRTUELE_BIB/Watertechniek/350_Waterbehandeling/353.1_HEN_E5_Manual_Design.pdf.pdf (accessed on $07 \overline{J u l y} 2017$ ).

29. SOMES N., HOBAN A., LEINSTER S. Guidelines for filter media in biofiltration systems (Version 3.01). FAWB Facility for Advancing Water Biofiltration, 2009. Available online: http://graie.org/SOCOMA/IMG/pdf/FAWB_Filter_media_guidelines_v3 June_2009-2.pdf_(accessed on 07 July 2017).

30. MANAV DEMIR N., ATCI E.B., DEMIR S. Effects of varying inlet iron and manganese concentrations on slow sand filter performance. Sigma J. Eng. \& Nat. Sci. 34 (4), 505, 2016.

31. HEDEGAARD M.J., ARVIN E., CORFITZEN C.B., ALBRECHTSEN H-J. Mecoprop (MCPP) removal in full-scale rapid sand filters at a groundwater-based waterworks. Sci. Total Environ. 499, 257, 2014.

32. HOYLAND V.W., KNOCKE W.R., FALKINHAM III J.O., PRUDEN A., SINGH G. Effect of drinking water treatment process parameters on biological removal of manganese from surface water. Water Res. 66, 31, 2014.

33. LI X-K., CHU Z-R., LIU Y-J., ZHU M-T., YANG L., ZHANG J. Molecular characterization of microbial populations in full-scale biofilters treating iron, manganese and ammonia containing groundwater in Harbin, China. Bioresource Technol. 147, 234, 2013.

34. CHENG Q., NENGZI, L., BAO L., HUANG Y., LIU S., CHENG X., LI B., ZHANG J. Distribution and genetic diversity of microbial populaions in the pilot-scale biofilter for simultaneous removal of ammonia, iron and manganese from real groundwater. Chemosphere. 182, 450, 2017.

35. YANG L., LI X., CHU Z., REN Y., ZHANG J. Distribution and genetic deversity of the microorganisms in the biofilter for the simultaneous removal of arsenic, iron and manganese from simulated groundwater. Bioresource Technol. 156, 384, 2014.

36. AYDIN M.E. Effects of design and operational variables on filtrate quality of slow sand filters. Pamukkale University Engineering College Journal of Engineering Sciences. 4 (1-2), 527, 1998.

37. BAR-ZEEV E., BELKIN N., LIBERMAN B., BERMAN T., BERMAN-FRANK I. Rapid sand filtration pretreatment for SWRO: Microbial maturation dynamics and filtration efficiency of organic matter. Desalination. 286, 120, 2012.

38. LINLIN W., XUAN Z., MENG Z. Removal of dissolved organic matter in municipal effluent with ozonation, slow sand filtration and nanofiltration as high quality pre-treatment option for artificial groundwater recharge. Chemosphere. 83, 693, 2011.

39. ZHENG X., ERNST M., JEKEL M. Pilot-scale investigation on the removal of organic foulants 
in secondary effluent by slow sand filtration prior to ultrafiltration. Water Res. 44, 3203, 2010.

40. JIN X., COLLING T., NDIONGUE S. Indicators of filter ripening for slow sand filter. WCWC Walkerton Clean Water Centre, $16^{\text {th }}$ Canadian National Conference on Drinking Water, Oct 26-29, 2014. Available online: http://www.cwwa.ca/pdf files/16DWC_presentations/D3-Jin.pdf (accessed on 07 July 2017).
41. HO L., MEYN T., KEEGAN A., HOEFEL D., BROOKES J., SAINT C.P., NEWCOMBE G. Bacterial degradation of microcystin toxins within a biologically active sand filter. Water Res. 40, 768, 2006. 